Mikalai Shepelevich, PhD in Engineering Science, Head of the scientific and research laboratory, Institute BeINIIS RUE (Minsk, Belarus)

Aliaksei Puzan, Master in Engineering Science, Construction Engineer, Institute BeINIIS RUE (Minsk, Belarus)

\title{
STUDYING CRACK RESISTANCE OF REINFORCED-CONCRETE - FIBRE-GLASS COMPOSITE PRESSURE PIPES FOR MICROTUNNELING
}

(C) РУП “Институт БелНИИС", 2019 Institute BeINIIS RUE, 2019

\section{ABSTRACT}

The results are given for experimental studies of crack resistance of reinforced-concrete - fibre-glass composite pressure pipes when affected by three-way load and internal hydrostatic pressure. Pipes are designed for construction of pressure pipelines, using the trenchless laying (microtunneling) method. BelNIIS Institute Republican Unitary Enterprise (RUE) has developed the design solutions and engineering drawings of pipes in accordance with the order placed by Steklokompozit Industrial Company, Russia. Pipes are made as integrated ones, and they consist of an external thick-wall reinforcedconcrete pipe (the cage) enveloping an insert pipe made of fibre-glass composite. Full-scale specimens of pipes with the inner diameter of $800 \mathrm{~mm}$ and the ("effective") length of $3000 \mathrm{~mm}$ were used for studies. The total thickness of pipe wall was $138 \mathrm{~mm}$, with the fibreglass composite insert thickness $10 \mathrm{~mm}$. Pipes were made in vertical position, with the vibroforming method used for this purpose. During the concrete mixture laying procedure, the fibre-glass composite insert pipe joined with the fibre-glass composite sleeve was used as a "permanent" formwork.

The experimental studies were carried out in two steps: 
I - pipes (2 specimens) were tested by the internal hydrostatic pressure;

II - pipes (2 specimens), including a hydraulically-tested specimen, were tested by the three-way load (according to GOST 6482). During the tests, formation and opening of cracks in longitudinal cross-sections of pipe wall was registered.

It was found that strength characteristics of integrated reinforcedconcrete composite pipes provide their load-carrying capacity against both the internal hydraulic pressure and the external (three-way) load applied. Thus, when reference loads in terms of crack resistance were applied, there were no cracks in longitudinal cross-sections of pipes; when reference loads in terms of strength were applied, the crack opening width never exceeded $0.05 \mathrm{~mm}$. Also, both with the internal pressure and the three-way load applied, the crack opening widths in longitudinal cross-sections of a reinforced-concrete cage were significantly (1.5...2.5 times) less than the corresponding values resulting from pipe design calculations carried out in accordance with procedures being in force.

Keywords: integrated reinforced-concrete - fibre-glass composite pressure pipes, tests by loading, internal pressure, strength and crack resistance, crack opening width.

For citation: Shepelevich M., Puzan A. Studying crack resistance of reinforced-concrete - fibre-glass composite pressure pipes for microtunneling. Contemporary Issues of Concrete and Reinforced Concrete: Collected Research Papers. Minsk. Institute BelNIIS. Vol. 11. 2019. pp. 76-88. https://doi.org/10.35579/2076-6033-2019-11-06

Шепелевич Николай Иосифович, канА. техн. наук, Аоцент, заведующий научно-исследовательской лабораторией, РУП “Институт БелНИИС" (г. Минск, Беларусь)

Пузан Алексей Сергеевич, магистр техн. наук, инженер-конструктор, РУП «Институт БелНИИС» (г. Минск, Беларусь) 


\section{ИССАЕАОВАНИЯ ТРЕЩИНОСТОЙКОСТИ ЖЕАЕЗОБЕТОННО-СТЕКАОКОМПОЗИТНЫХ НАПОРНЫХ ТРУБ АМЯ МИКРОТОННЕАИРОВАНИЯ}

\section{АННОТАЦИЯ}

Приведены результаты экспериментальных исследований трещиностойкости железобетонно-стеклокомпозитных напорных труб при действии трехлинейной нагрузки и внутреннего гидростатического давления. Трубы предназначены для строительства напорных трубопроводов методом бестраншейной прокладки (методом микротоннелирования). Конструктивные решения и рабочие чертежи труб разработаны РУП «Институт БелНИИС» по заказу ПО «Стеклокомпозит» (Россия). Трубы выполнены комплексными и состоят из внешней толстостенной железобетонной трубы (обоймы), охватывающей стеклокомпозитную трубу-вкладыш. Исследования произведены с использованием натурных образцов труб внутренним диаметром 800 мм $u$ длиной («полезной») 3000 мм. Суммарная толщина стенки трубы составляла 138 мм при толщине стеклокомпозитного вкладыша 10 мм. Трубы изготовлены в вертикальном положении методом виброформования. При укладке бетонной смеси стеклокомпозитная труба-вкладыи, состыкованная со стеклокомпозитной муфтой, использовалась как «несъемная» опалубка.

Экспериментальные исследования выполнены в два этапа:

I - трубы (2 образца) испытаны внутренним гидравлическим давлением;

II - трубы (2 образца), в т. ч. образец, прошедший гидравлические испытания, испытаны трехлинейной нагрузкой (по ГОСТ 6482). В процессе испытаний фиксировали образование и раскрытие трещин в продольных сечениях стенки трубы.

Установлено, что прочностные характеристики комплексных железобетонно-композитных напорных труб обеспечивают их несушую способность как при внутреннем гидравлическом давлении, так и под действием внешней (трехлинейной) нагрузки. Так, при контрольных нагрузках по трещиностойкости трещины в продольных сечениях труб отсутствовали, а при контрольных 
нагрузках по прочности ширина раскрытия трещин не превышала 0,05 мм. При этом как при действии внутреннего давления, так и при трехлинейной нагрузке ширина раскрытия трещин в продольных сечениях железобетонной обоймы существенно (в 1,52,5 раза) меньше, чем соответствующие значения, полученные в результате расчета труб по действующим методикам.

Ключевые слова: комплексные железобетонно-стеклокомпозитные напорные трубы, испытания нагружением, внутреннее давление, прочность и трещиностойкость, ширина раскрытия трещин.

Для цитирования: Шепелевич, $\mathrm{H}$. И. Исследования трещиностойкости железобетонно-стеклокомпозитных напорных труб для микротоннелирования / Н. И. Шепелевич, А. С. Пузан // Проблемы современного бетона и железобетона : сб. науч. тр. / Ин-т БелНИИС; редкол.: О. Н. Лешкевич [и др.]. - Минск, 2019. Вып. 11. - С. 76-88. https://doi.org/10.35579/2076-6033-2019-11-06

\section{INTRODUCTION}

The structures of integrated reinforced-concrete - fibre-glass composite pipes designed for construction of pressure pipelines, using the trenchless laying (microtunneling) method, were developed by BelNIIS Institute RUE in accordance with the order placed by Steklokompozit Industrial Company, Russia. Until now, construction of pressure pipelines with the diameter greater than $600 \mathrm{~mm}$, using the trenchless laying method, was carried out in two stages. During the first stage, a large-diameter tunnel was built using, for example, usual reinforced-concrete non-pressure pipes for microtunneling; then, a pressure pipeline made of polymer pipes was laid in a tunnel. Then, the space between pipes was filled with concrete (fully or partially) [1]. This technology is obviously labour-, material- and time-consuming.

In recent years, fibre-glass composite microtunnel pipes made by HOBOS company were introduced in the world practice for trenchless laying of pressure pipelines. Unlike usual pressure fibre-glass composite pipes (laid in a trench), pipes for microtunneling must have thick walls (to accept ramming forces), and their cost is significant. 
Thus, pressure pipes for microtunneling must comprise positive characteristics (such as compressive strength) of reinforced concrete and must be watertight when the internal pressure exists. It seems to be obvious that integrated reinforced-concrete - fibre-glass composite pressure pipes meet these requirements, with their inner fibre-glass composite core serving as a watertight barrier and the outer reinforced concrete cage providing strength of longitudinal and annular crosssections of pipes. Application of integrated reinforced-concrete fibre-glass composite pressure pipes will make it possible to reduce significantly the cost of construction of pressure pipelines using the trenchless laying method.

Until now, integrated reinforced-concrete - fibre-glass composite pressure pipes were never used for trenchless driving, and no technical documents available for their calculation and design. As for usual reinforced-concrete pressure pipes, as a rule, they are made pre-stressed. Pre-stressing provides crack resistance of pipe walls when affected by the internal pressure and external load. However, the reinforced-concrete pressure pipe production technology (e. g. vibration hydraulic pressing) is sophisticated, and it requires special costly equipment [2]. It's virtually impossible to make reinforcedconcrete pressure pipes for microtunneling using this technology.

The purpose of studies is the development of design solutions for integrated reinforced-concrete - fibre-glass composite pipes and studying their load-carrying capacity (crack resistance).

\section{DESIGN SOLUTION}

The design solution for a reinforced-concrete - fibre-glass composite pressure pipe is based on making a fibre-glass composite core (with thickness of $8 \ldots 25 \mathrm{~mm}$, depending on the diameter of pipes) within a usual (non-pressure) reinforced-concrete pipe. This technical solution can be implemented on the equipment being in operation for production of reinforced-concrete pipes for microtunneling. See Figure 1 for photos of pilot specimens of integrated reinforced-concrete - fibre-glass composite pressure pipes with the diameters of $800 \mathrm{~mm}$ and $2000 \mathrm{~mm}$, made using the molding technology (vibroforming) [3]. The fibre-glass composite sleeve is set in the pipe socket, in addition 
to the steel shell ring (see the photo on Figure 2), and the fibre-glass composite insert protrudes by $150 \ldots 180 \mathrm{~mm}$ beyond the bushing of the reinforced-concrete cage providing their secure coupling.

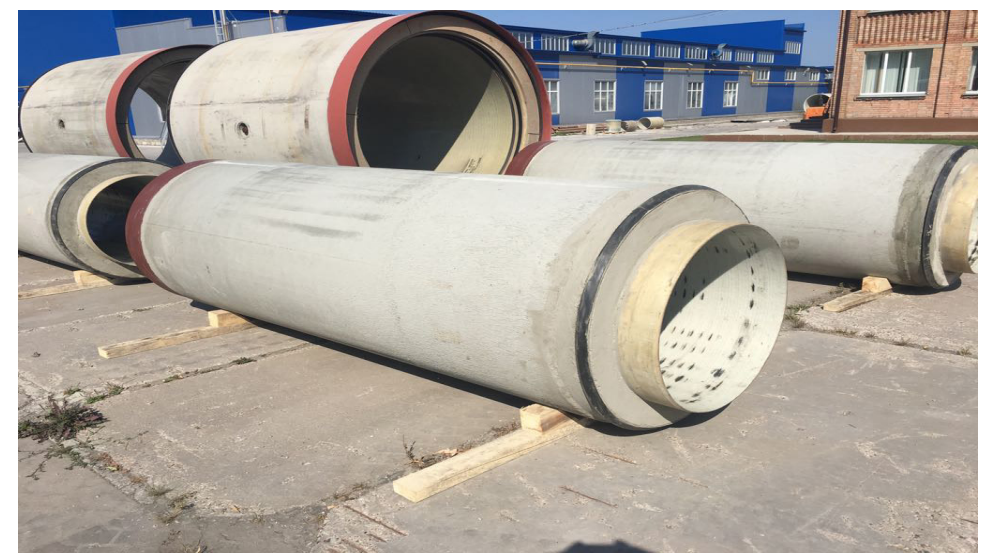

Figure 1. Appearance of pilot specimens of pipes with the diameter of 800 and $2000 \mathrm{~mm}$.

As for the design of these structures, standard procedures such as those in accordance with the "Manual..." [4] used for the design of pressure pipes are inapplicable here. It seems that a standard pressure pipe made of fibre-glass composite can be simply taken and placed into a reinforced-concrete (non-pressure) microtunnel pipe. Here, a fibreglass composite pipe will accept the internal hydraulic pressure and a reinforced-concrete cage will accept the external load and the ramming force (during driving). However, this structure will work differently. The modulus of deformation of reinforced concrete is $20 \ldots 30$ times higher than the modulus of deformation of fibre-glass composite; as a result, when a pipe is affected by combination of the internal pressure and the external load, pressure will be transferred to the reinforcedconcrete cage resulting in its destruction followed by destruction of the fibre-glass composite pipe.

No crack formation is tolerable in reinforced-concrete pressure pipes. Crack resistance of longitudinal cross-sections of the pipe wall is provided by pre-stressed spiral reinforcement and checked by calculation. In our case, however, there is no pre-stressing, and due to 
the watertight fibre-glass composite core included, crack opening can be tolerated in longitudinal cross-sections of the reinforced-concrete cage. However, crack opening width shall be limited. Otherwise, for such a pipeline, its service life will be the function of steel reinforcement corrosion rate in cross-sections with cracks.

To calculate crack resistance of integrated reinforced-concrete fibre-glass composite pressure pipes, the procedure of calculation of crack opening width in longitudinal cross-sections of reinforcedconcrete non-pressure pipes [5] can be used. The procedure is based on application of the standard procedure where the numerical method and computer modeling is used to calculate distance between cracks. For this calculation, the pipe element (the ring) affected by planar deformation is considered. For modeling of concrete, planar elements rigidly connected to each other are used; for modeling of reinforcement, rod elements connected (at junctions) with planar elements are used. A fibre-glass composite insert is defined by rod or planar elements bound (at junctions) with concrete elements in radial direction only. The calculation shall be carried out in two stages: 1 - calculation in terms of effects of external loads; 2 - calculation in terms of the internal pressure.

Preliminary calculations have demonstrated that, to accept the hydrostatic pressure of $1.0 \mathrm{MPa}$, a reinforced-concrete microtunnel pipe with the diameter of $800 \mathrm{~mm}$ and wall thickness of $138 \mathrm{~mm}$ (set in accordance with the conditions of acceptance of ramming forces) must be reinforced by two cylindrical frameworks with the operating (spiral) reinforcement having the diameter of $10 \mathrm{~mm}$, S500 class, and the pitch of $80 \mathrm{~mm}$. The design class of concrete shall be $\mathrm{C}^{32} /{ }_{40}$. The maximum opening width for the design load is $0.25 \mathrm{~mm}$. However, the fibre-glass composite insert thickness has no significant influence on the load-carrying capacity of pipes, and it is reasonable to specify it in accordance with the design considerations and manufacturing technology. For a pipe with the diameter of $800 \mathrm{~mm}$, the fibre-glass composite insert thickness is assumed to be $8.5 \mathrm{~mm}$.

To draft the procedure for analysis of reinforced-concrete - fibreglass composite pressure pipes in terms of strength and crack resistance, full-scale specimens of pipes with the diameter of $800 \mathrm{~mm}$ were tested by internal hydrostatic pressure and three-way load. 


\section{TEST PROCEDURE AND RESULTS}

Studies were carried out in two stages. During the stage 1, the pipes (2 specimens) were tested by internal hydrostatic pressure, with the equipment for hydraulic tests of fibre-glass composite pressure pipes used for this purpose. Because the distance between the plugs of the test bench was $12 \mathrm{~m}$, two integrated reinforced-concrete - fibre-glass composite pipes, each of them $3 \mathrm{~m}$ long, and one standard fibre-glass composite pressure pipe, $6 \mathrm{~m}$ long, were coupled. Tests were carried out in accordance with the procedure set by GOST 12586.0 [6], using the hydraulic test bench at Steklokompozit Industrial Company (see Figure 2).

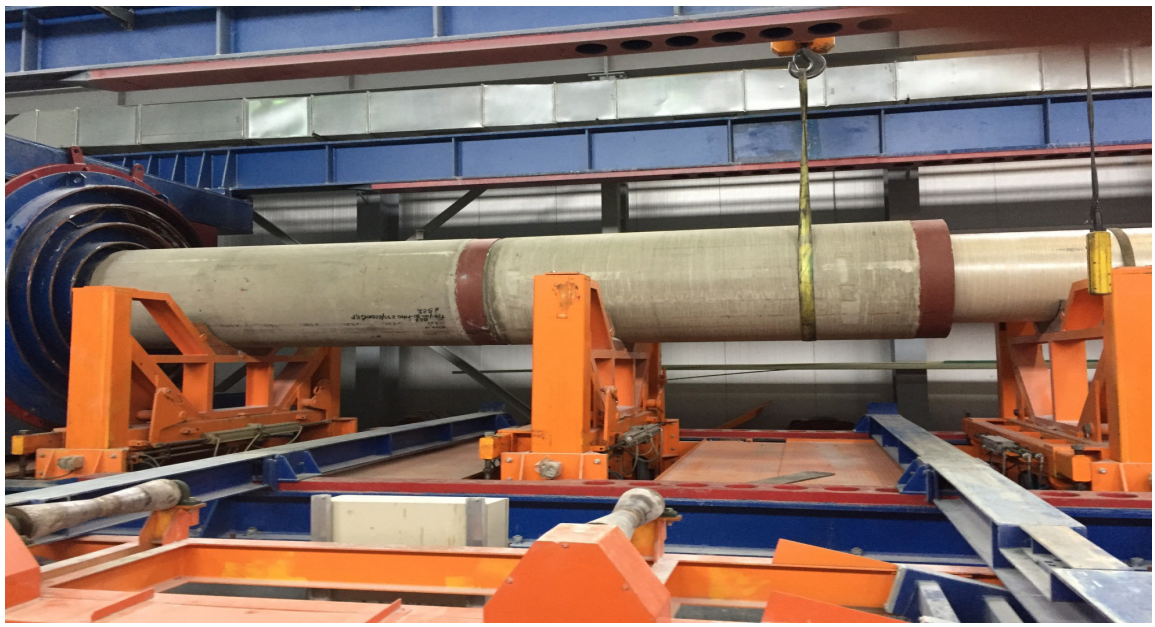

Figure 2. Appearance of pipes during the hydraulic tests

Pressure was raised with the rate of $0.1 \mathrm{MPa}$ per minute up to the reference value in terms of water tightness (1.2 $\mathrm{MPa}$ ) and, after the time delay, visual inspection of pipes was carried out. No water infiltrations through the pipe wall or through the butt joint were found. Then, pressure was raised up to the reference value in terms of crack resistance (1.68 MPa). There were no cracks in pipes. Then, the internal pressure was raised stepwise, with $0.1 \mathrm{MPa}$ increments, and pipe surfaces were visually inspected for cracks. 
First longitudinal cracks with the opening width up to $0.05 \mathrm{~mm}$ arose on the concrete surface of the pipe spigot end (behind the steel shall ring) at the pressure of $1.75 \mathrm{MPa}$. For the pressure of $2.5 \mathrm{MPa}$, the maximum crack opening width was $0.15 \mathrm{~mm}$; for $2.65 \mathrm{MPa}, 0.25 \mathrm{~mm}$. Tests were terminated with the internal pressure of $2.7 \mathrm{MPa}$ due to the rupture of the standard fibre-glass composite pressure pipe.

See Figure 3 for the appearance and location of cracks at the surface of the reinforced-concrete cage near the butt joint of pipes. In total, 8 cracks arose, (almost) uniformly distributed on the side surface of the reinforced-concrete cage (see Figure 3). The distance between cracks (along an arc) at the pressure of $2.65 \mathrm{MPa}$ was $350 \ldots 400 \mathrm{~mm}$. After the release of the internal pressure, cracks in the reinforced-concrete cage closed (with the residual crack opening width $0.04 \ldots 0.05 \mathrm{~mm}$ ).

Then, two pipes (including one pipe after hydraulic tests) were tested in accordance with the three-way pattern as described in the procedure of GOST 6482 [7]. Tests were carried out in the experimental building of BelNIIS Institute RUE. Load was applied stepwise, with 33.4 $\mathrm{kN} / \mathrm{m}$ increments and 10-minute delays at each step; onset of cracks and their opening widths in longitudinal cross-sections of the pipe wall were recorded, and measurements of annular cross-section warping and the fibre-glass composite insert peeling from the reinforcedconcrete cage were carried out (see Figure 4).

During the test of the specimen no.1 (that has previously passed the hydraulic test), no new cracks arose in the pipe wall. Also, there was no growth of opening width of existing cracks under the reference load in terms of crack resistance $(168.3 \mathrm{kN} / \mathrm{m})$, and under the reference load in terms of strength $(306.0 \mathrm{kN} / \mathrm{m})$, this opening width was $0.06 \ldots 0.10 \mathrm{~mm}$. Growth of the horizontal diameter of an annular cross-section of a pipe was $0.62 \mathrm{~mm}$ under the reference load in terms of crack resistance, and $1.82 \mathrm{~mm}$ under the reference load in terms of strength. Peelings of the fibre-glass composite insert from the reinforced-concrete cage (i.e. the gap between them) were recorded only at the pipe top, and their maximum size (at the centre) was 0.17 $\mathrm{mm}$ under the reference load in terms of crack resistance, and $0.55 \mathrm{~mm}$ under the reference load in terms of strength. The specimen was not carried to failure $\left(\mathrm{P}_{\max }=368.3 \mathrm{kN} / \mathrm{m}\right)$. 


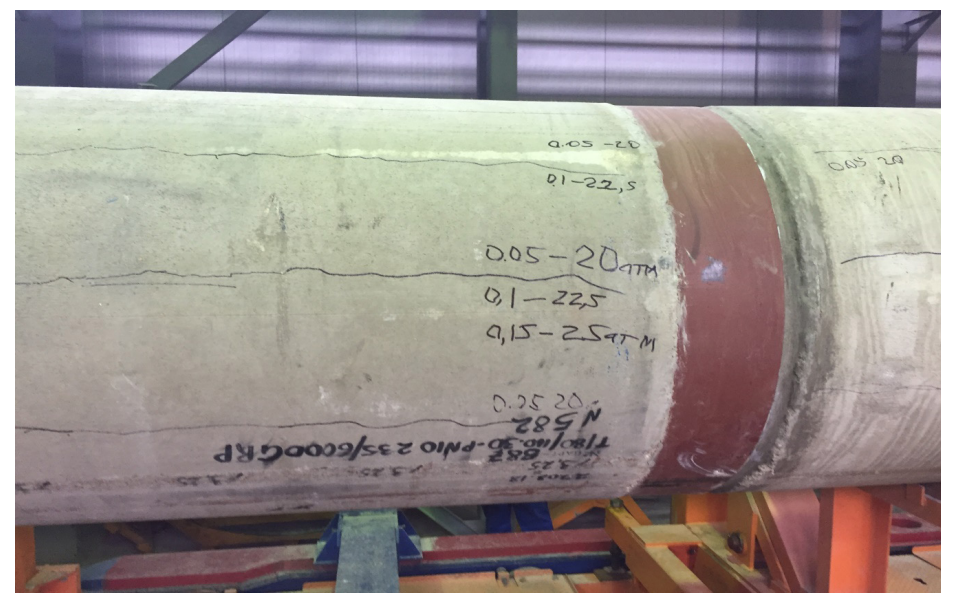

Figure 3. Cracking pattern on the concrete surface of pipes

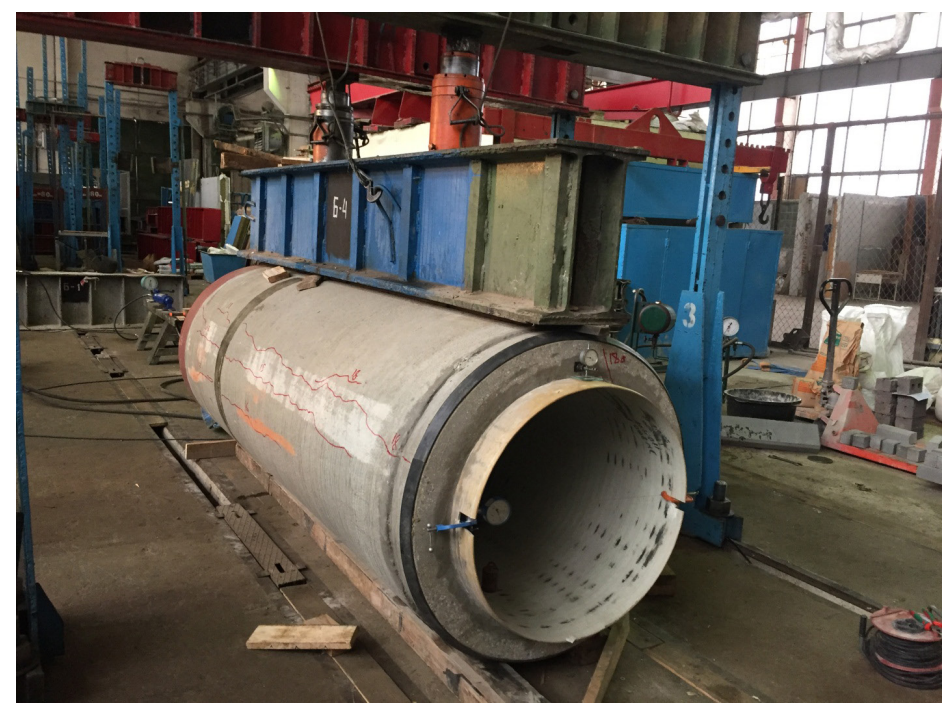

Figure 4. Pipe appearance during the three-way pattern test

During the test of the specimen no.2 (the new pipe), the first cracks with the opening width of 0.05-0.06 mm were detected only under the reference load in terms of strength $(306.0 \mathrm{kN} / \mathrm{m})$. Under the load of $435.0 \mathrm{kN} / \mathrm{m}$, their opening width was $0.2 \ldots 0.25 \mathrm{~mm}$. The 
annular cross-section warping was $0.21 \mathrm{~mm}$ under the reference load in terms of crack resistance, and $0.62 \mathrm{~mm}$ under the reference load in terms of strength.

Peelings of the fibre-glass composite insert from the reinforcedconcrete cage (i.e. the gap between them) were recorded only at the pipe top, and their maximum size (at the centre) was $0.09 \mathrm{~mm}$ under the reference load in terms of crack resistance, and $0.36 \mathrm{~mm}$ under the reference load in terms of strength. The failure of the specimen no.2 took place due to the pipe top punching by the loading beam (along the oblique section; for the photo, see Figure 5) under the load of $457.0 \mathrm{kN} / \mathrm{m}$.

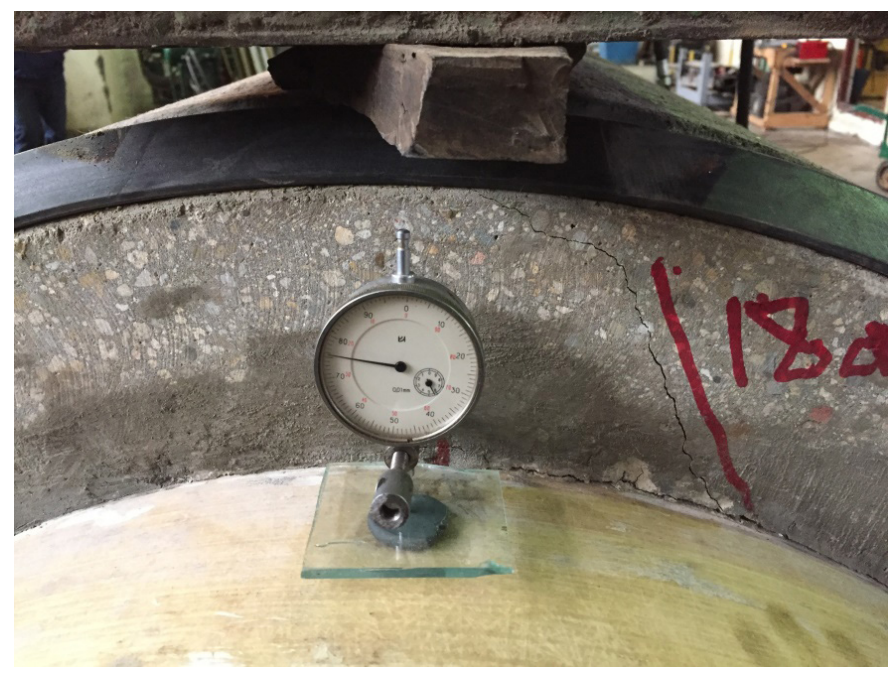

Figure 5. Appearance of the pipe top with a crack

It should be noted that reinforced-concrete - fibre-glass composite pipes are not inferior to similar reinforced-concrete pre-stressed pipes in terms of crack resistance characteristics obtained in pipe tests by the internal pressure and tests by the three-way load. For example, crack resistance tests for pilot specimens of reinforced-concrete pressure pipes, $2^{\text {nd }}$ class (the operating pressure is $1.0 \mathrm{MPa}$ ), made using the vibration hydraulic pressing method, have demonstrated that the first cracks in the pipe wall longitudinal cross-section arise under the 
internal pressure of 1.9...2.0 MPa. In tests of pipes by the three-way load, first cracks arise in the pipe top at loads of $170 \ldots 180 \mathrm{kN} / \mathrm{m}$, and pipe failure takes place at loads of $350 \ldots 380 \mathrm{kN} / \mathrm{m}$ [8].

\section{CONCLUSIONS}

The results of studies have demonstrated that the integrated reinforced-concrete - fibre-glass composite pressure pipes designed by BelNIIS Institute RUE provide acceptance of the design loads. However, the crack opening width in longitudinal cross-sections of reinforcedconcrete walls of pipes is 2-3 times less than the values calculated in accordance with procedures being in force.

According to the results of further studies (including those for other diameters of pipes), recommendations will be drafted for calculation and design of integrated reinforced-concrete - fibre-glass composite pressure pipes.

\section{REFERENCES}

1. Mikrotonnellirovaniye. Pravila i kontrol vypolneniya, trebovaniya $k$ rezultatam rabot [Microtunneling. Performance rules and control, requirements for the results of works]: STO Novostroy 2.27.124-2013. 85 p. (rus)

2. Tevelyev Yu. A. Publishing House of Construction Universities Association. 2004. pp. 64-96. (rus)

3. Becker G. Razlichnyye koncepcii proizvodstva trub [Various concepts for pipe production]. Concrete-Batching Plant. 2005. № 1. pp. 35-40. (rus)

4. Rukovodstvo po raschetu i proyektirovaniyu zhelezobetonny$k h$ napornykh predvaritelno-napryazhennykh trub [Manual for calculation and design of reinforced-concrete pre-stressed pressure pipes]. M.: Stroyizdat Publishing House, 1977. 37 p. (rus)

5. Shepelevich N., Molchan A. (2012) Crack Opening Width Calculation Method for Non-Pressure Reinforcend-Concrete Pipes. Advanced Construction. Proceedings of the 3d International conference. pp. 70-75. 
6. Truby zhelezobetonnyye napornyye vibrogidropressovannyye. Tekhnicheskiye usloviya [Reinforced-concrete pressure pipes made using the vibration hydraulic pressing method. Technical Conditions]. GOST 12586.0-83. Introduced: 01.01.1985. M.: Publishing House of Standards, 1984. 18 p. (rus)

7. Truby zhelezobetonnyye beznapornyye. Tekhnicheskiye usloviya [Reinforced-concrete non-pressure pipes. Technical Conditions. GOST 6482-2011. Introduced: 01.01.2013. M.: State Committee for Standards, 2013. 21 p. (rus)

8. Popov A. N., Tsionskiy A. L., Khripunov V. A. Proizvodstvo zhelezobetonnykh napornykh vibrogidropressovannykh trub [Production of reinforced-concrete pressure pipes made using the vibration hydraulic pressing method]. M.: Stroyizdat. 1979. pp. 187-202. (rus)

Received: 15.11.2019 